\title{
Ichthyofaunal Diversity and Water Quality in the Kangsabati Reservoir, West Bengal, India
}

\author{
Amalesh Bera, ${ }^{1}$ Manojit Bhattacharya, ${ }^{1}$ Bidhan Chandra Patra, ${ }^{1}$ and Utpal Kumar Sar ${ }^{2}$ \\ ${ }^{1}$ Aquaculture Research Unit, Department of Zoology, Vidyasagar University, Midnapore, West Bengal 721102, India \\ ${ }^{2}$ Department of Fisheries, Government of West Bengal, Meen Bhavan, Sepoy Bazar, Midnapore, West Bengal 721101, India \\ Correspondence should be addressed to Amalesh Bera; mbhattacharya09@gmail.com
}

Received 20 July 2014; Revised 27 October 2014; Accepted 4 December 2014; Published 31 December 2014

Academic Editor: Mauro Fasola

Copyright (c) 2014 Amalesh Bera et al. This is an open access article distributed under the Creative Commons Attribution License, which permits unrestricted use, distribution, and reproduction in any medium, provided the original work is properly cited.

\begin{abstract}
The ichthyofauna in relation to water quality was studied on monthly basis from March, 2010 to February, 2011 in the Kangsabati Reservoir, West Bengal. The study revealed that physicochemical parameters of Kangsabati Reservoir were congenial for 39 fish species of commercial importance, belonging to 7 orders, 15 families, and 26 genera. The Cypriniformes were dominant with 17 species, followed by Siluriformes and Perciformes, with 7 species each, Channiformes with 3 species, Osteoglossiformes and Synbranchiformes with 2 species each, and Anguilliformes with 1 species. Regarding their conservation status, 27 species were of least concern, 1 species was vulnerable, 6 species were near threatened, 1 species was data deficient, and 4 species were not evaluated (IUCN-Version 2014.1). Economical values have also been evaluated. Water parameters such as temperature, $\mathrm{pH}$, alkalinity, dissolved oxygen, hardness, free $\mathrm{CO}_{2}$, salinity, total inorganic nitrogen, and phosphate were recorded and found suitable for fish production. Conductivity, transparency, and high chloride level are minor limiting factor that may needs rectification for improved fisheries management.
\end{abstract}

\section{Introduction}

The aquatic ecosystem is highly dependent on water quality and biological diversity. Physicochemical parameters of water play a significant role in the biology and physiology of fish [1]. Lakes and reservoirs contribute to the single largest inland fishery resources in terms of both size and production potential. Fishes are the important indicator of aquatic ecosystem and occupy a remarkable position from a socioeconomic point of view. Fish is very rich source of protein as well as vitamins and other minerals. Kangsabati Reservoir is situated between $22^{\circ} 55^{\prime} 16.53^{\prime \prime} \mathrm{N}-23^{\circ} 2^{\prime} 30.41^{\prime \prime} \mathrm{N}$ latitude and $86^{\circ} 37^{\prime} 55.30^{\prime \prime} \mathrm{E}-86^{\circ} 47^{\prime} 23.35^{\prime \prime} \mathrm{E}$ longitude, about $67 \mathrm{Km}$ southwest from the Bankura District Town, West Bengal, India. The reservoir is used not only for irrigation but also for fish production by Fishery Department, Government of West Bengal, through the involvement of local fishermen communities. The structure of fish community, fish distribution, and ichthyofauna diversity has been reported by various workers in the different lakes and reservoirs [219]. But comprehensive information of Kangsabati Reservoir
(Figure 1) on fish diversity in relation to water quality is inadequate to frame a tangible fisheries programme.

In the present study, our main aim was to evaluate the suitability of water to nurture fishery activity, by recording water parameters. We describe the fish diversity in Kangsabati reservoir, in connection with the physicochemical parameters of water, in order to formulate future planning for the development of the socioeconomic status of fishermen.

\section{Materials and Methods}

The study was conducted every last week of each month, between 6.00 and 8.00 a.m. The fish samples were captured with the help of local skilled fishermen in three preselected sampling sites. Dragnet, Castanet, Scoop net, Basket trap, and so forth were used for capturing fish. Fish species available at the local market and caught by local fishermen from the reservoir were also purchased. All fish species were preserved in $10 \%$ formaldehyde solution for identification to genus and species level using taxonomic keys and standard literatures [20-23]. 


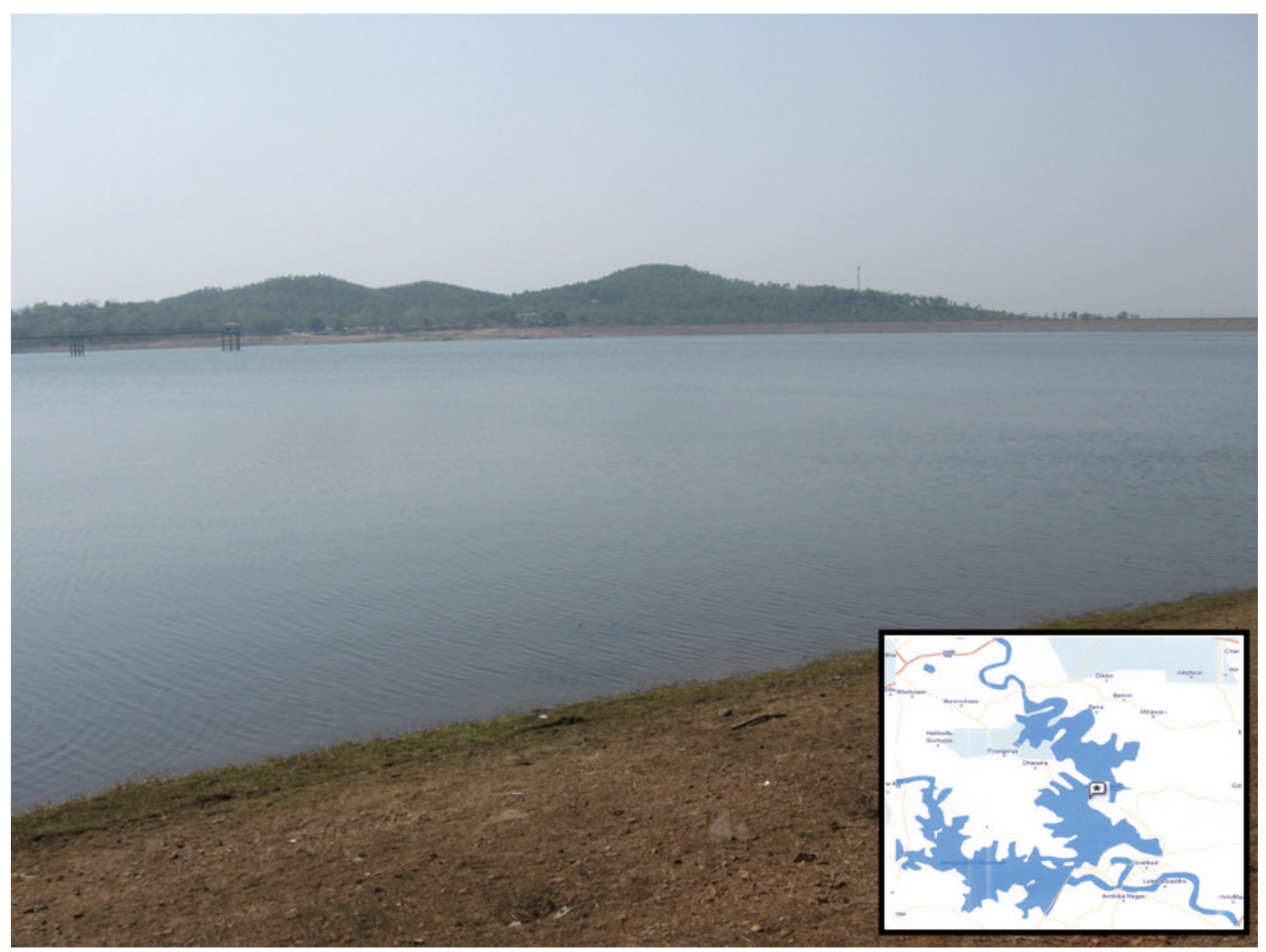

FIGURE 1: View of the Kangsabati Reservoir (blue shaded area indicating reservoir area in inset).

Samples of subsurface water were collected monthly in clean plastic air tight bottles at three stations (local names: Sadarghat, Aparajitaghat, and Peerlessghat) from March 2010 to February 2011, from 8 to 9.30 a.m. The water and air temperature were recorded by hydrothermometer and minimum-maximum thermometer, respectively; $\mathrm{pH}$ recorded by digital $\mathrm{pH}$ meter (Cystronics model 335); conductivity analyzed by conductivity meter (Labtronics model LT 16); dissolved oxygen examined by Winkler's method; photic depth measured by Secchi disc method; free $\mathrm{Co}_{2}$, alkalinity, chlorinity, phosphorus, total inorganic nitrogen, calcium, magnesium and hardness were calculated as standard laboratory protocol [24]. The diversity was calculated on number of species, while the orders were used to calculate the Shannon-Wiener index.

\section{Results}

The value of water parameters is depicted in Table 1 , and the data on the fish community of the Kangsabati Reservoir are presented in Tables 2, 3, and 4. The periodical survey of the ichthyofauna revealed the occurrence of 39 species belonging to 15 families, 26 genera, and 7 orders. On the basis of species composition, Cypriniformes were dominant (17 species) followed by Siluriformes and Perciformes (each of 7 species), Channiformes (3 species), Osteoglossiformes and Synbranchiformes (each of 2 species), and Anguilliformes (1 species).

\section{Discussion}

Among the studies on ichthyofaunal diversity previously conducted for our region in large aquatic bodies like the Kangsabati Reservoir, [25] reported the occurrence of 26 fish species belonging to 5 orders, 7 families, and 15 genera in Godavari river at Mudgal. The order Cypriniformes was dominant with 15 species, followed by Siluriformes with 5 species, Channiformes with 4 species, and Mastacembeliformes and Perciformes with 1 species each. Similar results, a total of 29 fish species belonging to 10 families, 7 orders, and 15 genera were reported for the Halali Reservoir, Vidisha, Madhya Pradesh [26].

The aquatic habitat and water quality parameters affect the fish growth and development and ichthyofaunal diversity. Temperature is the important factor for the aquatic biota. According to FAO report [31], the increase of temperature directly or indirectly impacts species distribution and the seasonality of production in fishes. According to the guidelines for water quality management for fish culture in Tripura, the suitable water temperature for carp culture ranges between $24^{\circ} \mathrm{C}$ and $30^{\circ} \mathrm{C}$. So, the water temperature of Kangsabati Reservoir was very suitable, except a minute fall during the winter season.

Transparency helps to assess the quality of water. According to [32] a turbidity ranging from 30 to $80 \mathrm{~cm}$ is good for fish health. On the other hand, according to guidelines for water quality management for fish culture in Tripura [33], 
TABle 1: Seasonal variation of physicochemical parameters of the water in Kangsabati Reservoir, March 2010-February 2011.

\begin{tabular}{|c|c|c|c|}
\hline $\begin{array}{l}\text { Parameters } \\
\text { (units) }\end{array}$ & $\begin{array}{c}\text { Summer season } \\
\text { (March-June) }\end{array}$ & $\begin{array}{l}\text { Rainy season } \\
\text { (July-October) }\end{array}$ & $\begin{array}{c}\text { Winter season } \\
\text { (November- } \\
\text { February) }\end{array}$ \\
\hline Air temperature $\left({ }^{\circ} \mathrm{C}\right)$ & $33.58-36.83$ & $31.06-35.83$ & $25.0-35.25$ \\
\hline Water temperature $\left({ }^{\circ} \mathrm{C}\right)$ & $28.16-31.50$ & $28.80-31.66$ & $18.33-27.83$ \\
\hline Transparency $(\mathrm{cm})$ & $40.83-181.66$ & $133.0-193.6$ & $188.1-308.5$ \\
\hline Conductivity $(\mu \mathrm{mho} / \mathrm{cm})$ & $15.73-17.11$ & $12.14-16.43$ & $11.95-14.47$ \\
\hline $\mathrm{pH}$ & $7.32-7.72$ & $7.38-7.98$ & $7.42-8.45$ \\
\hline D.O. (mg/L) & $7.20-9.00$ & $7.60-11.60$ & $10.40-12.00$ \\
\hline Alkalinity (mg/L) & $54.33-94.00$ & $40.67-79.66$ & $60.33-80.34$ \\
\hline Chloride $(\mathrm{mg} / \mathrm{L})$ & $132.91-305.3$ & $127.4-160.93$ & $110.9-160.40$ \\
\hline Phosphate (mg/L) & $0.014-0.041$ & $0.098-0.199$ & $0.037-0.062$ \\
\hline Total inorganic nitrogen $(\mathrm{mg} / \mathrm{L})$ & $0.50-1.08$ & $1.06-1.96$ & $0.74-1.02$ \\
\hline Hardness (ppm) & $115.18-178.6$ & $137.00-195.36$ & $112.60-170.60$ \\
\hline Salinity (ppt) & $0.26-0.57$ & $0.25-0.31$ & $0.22-0.31$ \\
\hline Photic depth $(\mathrm{cm})$ & $32.66-170.00$ & $117.00-176.60$ & $163.00-287.00$ \\
\hline Free $\mathrm{CO}_{2}(\mathrm{ppm})$ & $3.66-4.00$ & $3.33-7.00$ & $3.66-9.66$ \\
\hline Water level (ft) & $396.00-399.00$ & $405.00-432.80$ & $409.20-415.80$ \\
\hline Rainfall (average in $\mathrm{mm}$ ) & $4.30-138.20$ & $90.80-213.60$ & $0.00-34.80$ \\
\hline \multicolumn{4}{|l|}{ Plankton population } \\
\hline Plankton density (ind/L) & $1362-2183$ & $965-1681$ & $1253-2240$ \\
\hline
\end{tabular}

transparency between 30 and $40 \mathrm{~cm}$ indicates optimum productivity of a pond for good fish culture. High transparency value means that enough light penetrates and encourages macrophytes growth, so that less plankton is available as food for fish. Water transparency in the Kangsabati Reservoir was not completely satisfactory.

Electrical conductivity, comprising the total dissolved ions, is a good indicator of water chemistry. A certain level of ions in water is essential as nutrients for aquatic life [34]. According to the report of Southern Regional Aquaculture Centre (SRAC) [35], the desirable range of conductivity for fish culture is $60-2000 \mu \mathrm{mho} / \mathrm{cm}$. Our results showed values that were lower than the optimal limit. SRAC also reported that fresh water fish generally thrive over a wide range of electrical conductivity and that the upper range of tolerance varies with fish species.

$\mathrm{pH}$ is another important parameter for fish culture. According to the report of Northeastern Regional Aquaculture Centre (NRAC) [36], fish survive and grow best in waters with a $\mathrm{pH}$ between 6 and 9 . The $\mathrm{pH}$ values we recorded in the Kangsabati Reservoir remained within such safe range.

Reference [37] experimentally proved that dissolved oxygen is one of the most important parameters and a primary limiting factor controlling fish growth and survival. According to [38], D.O. should be above $5.0 \mathrm{mg} / \mathrm{L}$ for average or good production. Besides, [39] also reported that D.O. level $>5.0 \mathrm{mg} / \mathrm{L}$ is essential to support good fish production. The D.O. content in Kangsabati Reservoir was very satisfactory for fish culture.

Alkalinity of water is a measure of its capacity to neutralize acids. According to the guidelines for water quality management for fish culture in Tripura, the ideal value of alkalinity for fish culture is $50-300 \mathrm{mg} / \mathrm{L}$. According to the report of SRAC, the desirable limit for fish culture is 50 to $150 \mathrm{mg} / \mathrm{L}$, and the acceptable range is from 20 to $400 \mathrm{mg} / \mathrm{L}$. So, the alkalinity range of Kangsabati Reservoir permits the fisheries activity.

According to SRAC, more than $100 \mathrm{mg} / \mathrm{L}$ is the desirable range for commercial catfish production. So, the chloride value of the Kangsabati Reservoir was very high and stressful for fish culture. Higher chloride content may be due to contamination through large quantity of sewage input [26]. Higher concentration of chloride in water is an indicator of eutrophy [40]. The higher concentration of chloride in the Kangsabati Reservoir may be due to agricultural and sewage run-off during rain from the surrounding area of the reservoir and higher evaporation rate.

In most fresh waters, total hardness is mainly due to calcium and magnesium ions. According to the guidelines for water quality management for fish culture in Tripura, the ideal value of hardness for fish culture is $30-180 \mathrm{mg} / \mathrm{L}$. Reference [32] opined that $75-150 \mathrm{mg} / \mathrm{L}$ is optimum for fish culture. The hardness in Kangsabati Reservoir was slightly outside the desirable limits but did not reach harmful values. Some euryhaline species may have high tolerance limits to hardness [41].

Carbon di oxide is produced in water as a result of respiration of the aquatic organisms. According to the report of NRAC, the preferred range of free $\mathrm{CO}_{2} \leq 10 \mathrm{mg} / \mathrm{L}$. Besides, the guidelines for water quality management for fish culture in Tripura also mentioned that water supporting abundant fish populations should contain $\leq 5 \mathrm{mg} / \mathrm{L}$ free carbon dioxide. 


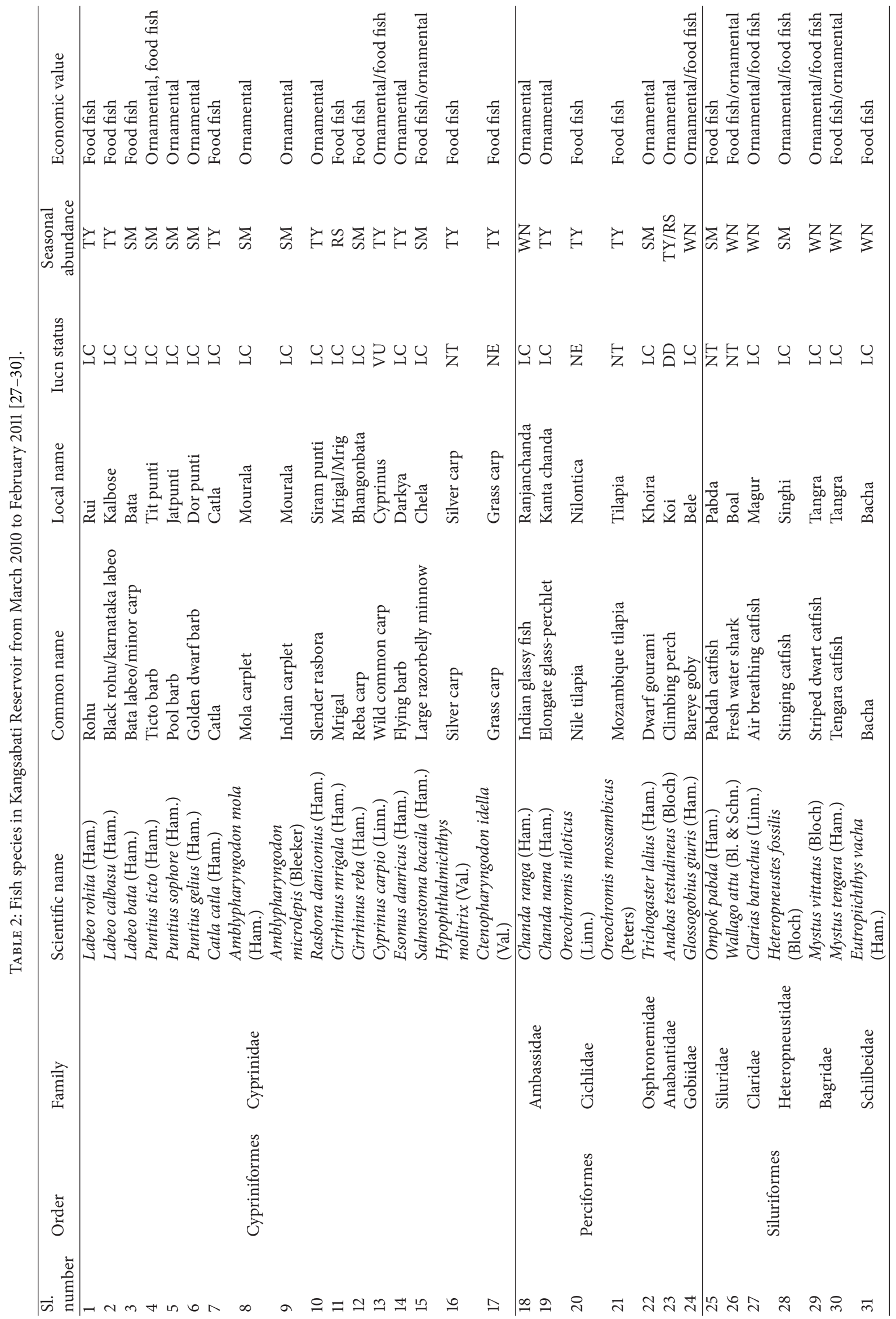




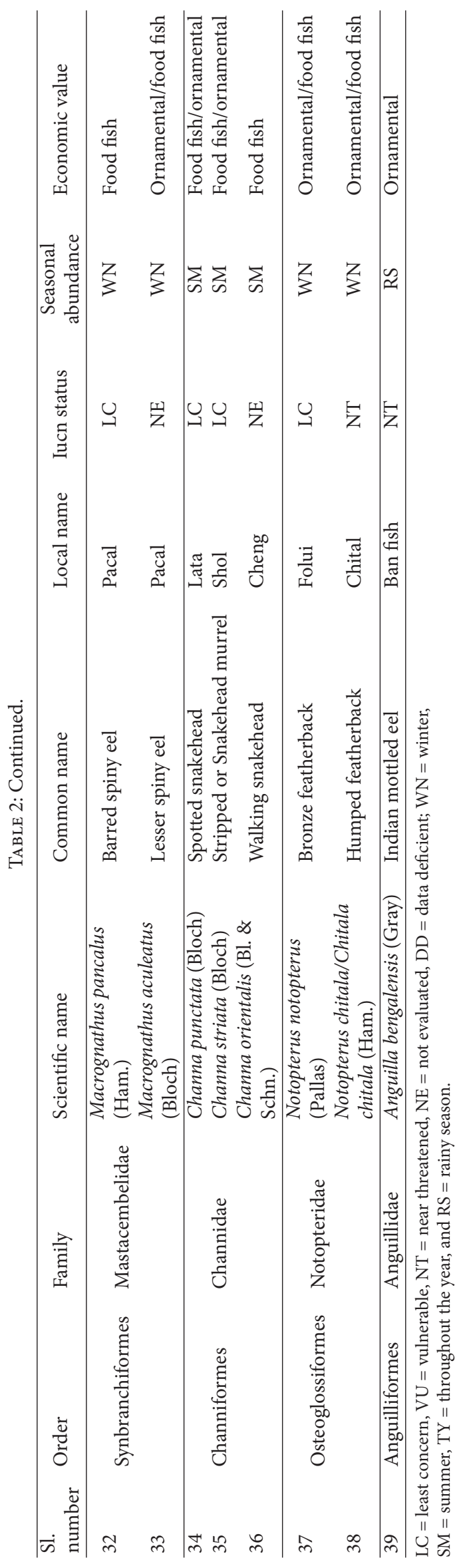


TABLE 3: Composition of the fish community by order.

\begin{tabular}{llcc}
\hline $\begin{array}{l}\text { Sl. } \\
\text { number }\end{array}$ & Taxa & $\begin{array}{c}\text { Number of } \\
\text { species }\end{array}$ & $\begin{array}{c}\text { Percentage } \\
(\%)\end{array}$ \\
\hline 1 & Order: Cypriniformes & 17 & 43.58 \\
2 & Order: Perciformes & 7 & 17.95 \\
3 & Order: Siluriformes & 7 & 17.95 \\
4 & Order: Channiformes & 3 & 7.69 \\
5 & Order: Osteoglossiformes & 2 & 5.13 \\
6 & Order: Synbranchiformes & 2 & 5.13 \\
7 & Order: Anguilliformes & 1 & 2.57 \\
\hline Total & & 39 & \\
\hline
\end{tabular}

TABLE 4: Composition of the fish community by family.

\begin{tabular}{llcc}
\hline $\begin{array}{l}\text { Sl. } \\
\text { number }\end{array}$ & Taxa/families & $\begin{array}{c}\text { Number of } \\
\text { Species }\end{array}$ & $\begin{array}{c}\text { Percentage } \\
(\%)\end{array}$ \\
\hline 1 & Family: Cyprinidae & 17 & 43.58 \\
2 & Family: Ambassidae & 2 & 5.12 \\
3 & Family: Cichlidae & 2 & 5.12 \\
4 & Family: Osphronemidae & 1 & 2.57 \\
5 & Family: Anabantidae & 1 & 2.57 \\
6 & Family: Gobiidae & 1 & 2.57 \\
7 & Family: Siluridae & 2 & 5.13 \\
8 & Family: Claridae & 1 & 2.57 \\
9 & Family: Heteropneustidae & 1 & 2.57 \\
10 & Family: Bagridae & 2 & 5.13 \\
11 & Family: Schilbeidae & 1 & 2.57 \\
12 & Family: Channidae & 3 & 7.69 \\
13 & Family: Notopteridae & 2 & 5.12 \\
14 & Family: Mastacembelidae & 2 & 5.12 \\
15 & Family: Anguillidae & 1 & 2.57 \\
\hline Total & & 39 & \\
\hline
\end{tabular}

Reference [41] clearly indicated an acceptable range of 0$10 \mathrm{mg} / \mathrm{L}$ and a desirable range of $<5,5-8 \mathrm{mg} / \mathrm{L}$ of free $\mathrm{CO}_{2}$ for high fish yield. The $\mathrm{CO}_{2}$ values we recorded for the Kangsabati Reservoir can strongly support fish culture.

Salinity limits may vary from species to species of fish [41]. According to the report of NRAC, the preferred ranges for fresh water fish culture are $<0.5-1.0 \mathrm{ppt}$. Our results fall within the limits given by NRAC.

Phosphorus is very critical in maintaining aquatic productivity. SRAC recommend desirable phosphate level for fish culture of $0.06 \mathrm{mg} / \mathrm{L}$, and the typical range for surface water is $0.005-0.5 \mathrm{mg} / \mathrm{L}$. Reference [41] reported an optimum range for phosphorus of $0.01-3.0 \mathrm{mg} / \mathrm{L}$. The value of phosphate in Kangsabati Reservoir matched the ranges given above. Reference [38] reported $0.05-0.20 \mathrm{ppm}$ range for medium to high productivity in fish ponds.

Nitrogen element is a vital component of protein and is essential for fish growth. FAO recommends desirable limit of total dissolved nitrogen for fish culture of $0.2 \mathrm{ppm}$. On the other hand, [38] reported TDN values of $0.2-0.5 \mathrm{ppm}$ as favourable for good productivity in ponds. Other than during the rainy season, the total level of inorganic or dissolved nitrogen in the Kangsabati Reservoir is acceptable for fish culture and does not hamper the fish production.

Throughout the year, water level in the Kangsabati Reservoir falls from April to June but still remains in adequate amount for fish cultivation.

Plankton is the chief food source for fish. According to [41], the desirable range of plankton density is 30004500 individual/L, and acceptable values are $\geq 2000$ individual/L. Both the zooplankton and the phytoplankton density together enhance the fisheries programme in our reservoir.

Therefore, each water quality parameter in the Kangsabati Reservoir remain within the limits suitable for fish production $[33,35,36,38,41]$. Most of the local workers reported that D.O., $\mathrm{pH}$, alkalinity, temperature, and hardness are the main factors which showed satisfactory results for fish culture in Kangsabati Reservoir. Salinity, phosphate, and free $\mathrm{Co}_{2}$, with the only exception of transparency and chloride level, also are favourable for good fish production. Conductivity was slightly variable throughout the study period and not completely favourable for pisciculture. A slight increase in planktonic density, as fish food, would be advisable. The end of the rainy season and the whole winter are the best and the healthier periods for fish growth.

We conclude that water quality in the Kangsabati Reservoir favours for fish cultivation and allows for a high ichthyofaunal diversity, with a value of 1.71 as per Shannon-Wiener index. We recommend the adoption of scientific fishery management, in order to regulate transparency and chloride level.

\section{Conflict of Interests}

The authors declare that there is no conflict of interests regarding the publication of this paper.

\section{Acknowledgments}

The authors are grateful to Dr. Aloknath Praharaj, Fishery officer, Govt. of West Bengal, India, for his valuable suggestions, kind help, and inspiration and to Mr. Ritish Das for laboratory assistance. We convey our special thanks to Mr. Samir Mandi for providing necessary support during the sample and field data collection.

\section{References}

[1] A. Dhawan and S. Kaur, "Pig Dung as pond manure: effect on water quality, pond productivity and growth of carps in polyculture system," Naga (ICLARM Quarterly), vol. 25, no. 1, pp. 11-14, 2002.

[2] A. Sreenivasan, "Limnology of tropical impoundments. I. Hydrological features and fish production in Stanley reservoir, Mettur Dam," Internationale Revue der Gesamten Hydrobiologie und Hydrographie, vol. 51, no. 2, pp. 295-306, 1966.

[3] K. K. Vass, A. Wanganeo, H. S. Raina, D. P. Zutshi, and R. Wanganeo, "Summer limnology and fisheries of high mountain 
lakes of Kashmir Himalaya," Archiv für Hydrobiologie, vol. 114, no. 4, pp. 603-619, 1989.

[4] L. M. Rao, "Hydrobiology and ichthyofauna of Mahendrigeda stream, Visakhapatnam (A.P.)," Journal of Aquatic Biology, vol. 13, no. 1-2, pp. 25-28, 1999.

[5] D. K. Kaushal, "Interrelationship of bottom fauna, fish and fisheries of Gobindsagar Reservoir, Himachal Pradesh," Indian Journal of Fisheries, vol. 47, no. 1, pp. 13-19, 2000.

[6] L. Sarkar and S. Benerjee, "Ichthyofauna of Damodar river system," Proceedings of the Zoological Society (Calcutta), vol. 53, no. 1, pp. 41-54, 2000.

[7] P. K. Joshi and V. B. Sakhare, "Ecology and Ichthyofauna of Bori reservoir in Maharashtra," Fishing Chimes, vol. 22, no. 4, pp. 4041, 2002.

[8] D. K. Mahapatra, "Present status of fisheries of Hirakund Reservoir, Orissa," Fishing Chimes, vol. 22, no. 10-11, pp. 76-79, 2003.

[9] S. V. A. Chandrasekhar, C. Nalini, and M. S. Kodarkar, "Limnological studies with reference to pisciculture, case study of Saroornagar Lake, Hyderabad (A.P.)," Journal of Aquatic Biology, vol. 19, no. 1, pp. 197-200, 2004.

[10] J. K. Balogun, "Fish distribution in a small domestic water supply reservoir: a case study of Kangimi reservoir, Kaduna, Nigeria," Journal of Applied Sciences and Environmental Management, vol. 9, no. 1, pp. 93-97, 2005.

[11] S. Patra, Studies on the biological aspects of Ansupa Lake, Orissa (India) [Ph.D. thesis], Utkal University, Bhubaneswar, India, 2006.

[12] J. Kantoussan, J. M. Ecoutin, M. Simier, G. Fontenelle, O. T. Thiaw, and R. Laë, "The relevance of species-based indicators as a tool for evaluating the structure of exploited fish assemblages: a comparative study of two tropical lakes in Mali, West Africa," Lakes \& Reservoirs: Research \& Management, vol. 12, no. 3, pp. 135-148, 2007.

[13] M. Y. Kulkarni, A. N. Kulkarni, and V. S. Somvanshi, "A study on some aspects of reservoir fisheries of Derala Tank, Dist-Nanded, Maharastra," in Proceedings of Taal 2007: The 12th World Lake Conference, pp. 568-570, 2008.

[14] B. A. Pawar and A. N. Shendge, "Studies on water quality of Ashwi Reservoir in relation to pisciculture, Ahmednagar district, Maharastra," Journal of Experimental Zoology India, vol. 12, no. 2, pp. 361-364, 2009.

[15] V. Keshre and L. K. Mudgal, "Study on fish diversity \& fish production of Moghat Reservoir, Khandwa (M.P.)," Journal of Environmental Conservation, vol. 11, no. 3, pp. 117-120, 2010.

[16] M. Singh, "Study of plankton abundance in fresh water fish pond at Malawan, Etah (UP)," Indian Journal of Biological Studies and Research, vol. 1, no. 1, pp. 39-44, 2011.

[17] N. Kumar, "Study on ichthyofaunal biodiversity of Turkaulia Lake, East-Champaran, Bihar, India," International Research Journal of Environmental Sciences, vol. 1, no. 2, pp. 21-24, 2012.

[18] A. S. Kumar Naik, S. Benakappa, S. R. Somashekara et al., "Studies on ichthyofaunal diversity of Karanja reservoir, Karnataka, India," International Research Journal of Environmental Sciences, vol. 2, no. 2, pp. 38-43, 2013.

[19] D. Basavaraja, J. Narayana, B. R. Kiran, and E. T. Puttaiah, "Fish diversity and abundance in relation to water quality of Anjanapura Reservoir, Karnataka, India," International Journal of Current Microbiology and Applied Sciences, vol. 3, no. 3, pp. 747-757, 2014.
[20] F. S. Day, The Fishes of India, William and Sons, London, UK, 1958.

[21] V. G. Jhingran, Fish and fisheries of India, Hindustan Publishing Corporation, New Delhi, India, 1975.

[22] K. C. Jayaram, The Freshwater Fishes of India, Pakistan, Bangladesh, Burma, and Sri Lanka: Handbook, Calcutta, India, ZSI, 1981.

[23] P. K. Talwar and A. G. Jhingran, Inland Fishes of India and Adjuscent Countries, vol. 1 and 2, Oxford and IBH Pub. Co. Pvt. Ltd., New Delhi, India, 1991.

[24] APHA, Standard Methods for Examination of Water and Waste Water, American Public Health Association, Washington, DC, USA, 21st edition, 2008.

[25] S. V. Rankhamb, "Ichthyofaunal diversity of Godavari River at Mudgal Tq. Pathri, dist. Parbhani," Recent Research in Science and Technology, vol. 3, no. 12, pp. 11-13, 2011.

[26] T. Yousuf, M. Ibrahim, H. Majid, J. Ahmad, and V. Vyas, "Ichthyofaunal diversity of Halali Reservoir, Vidisha, Madhyapradesh," International Journal of Scientific and Research Publications, vol. 2, no. 12, pp. 1-7, 2012.

[27] Fish Base, 2014, http://www.fishbase.org/search.php.

[28] IUCN, "IUCN Red List of Threatened Species (version 2014.1)," http://www.iucnredlist.org/.

[29] http://en.wikipedia.org/wiki/List_of_freshwater_aquarium_fish_ species.

[30] A. Basu, D. Dutta, and S. Banerjee, "Indigenous ornamental fishes of West Bengal," Recent Research in Science and Technology, vol. 4, no. 11, pp. 12-21, 2012.

[31] "FAO Fisheries and Aquaculture Department, Food and Agriculture Organization of the United Nations, Rome," The State of World Fisheries and Aquaculture, pp. 115-116, 2010.

[32] A. Bhatnagar, S. N. Jana, S. K. Garg, B. C. Patra, G. Singh, and U. K. Barman, "Water quality management in aquaculture," in Course Manual of Summer School on Development of Sustainable Aquaculture Technology in Fresh and Saline Waters, pp. 203-210, CCS Haryana Agricultural, Hisar, India, 2004.

[33] B. Santhosh and N. P. Sing, "Guidelines for water quality management for fish culture in Tripura," ICAR research complex for NEH region, Tripura Centre, Lembucherra-799 210, Tripura (west). Publication no. 29, 2007.

[34] C. Galbrand, I. G. Lemieux, A. E. Ghaly, R. Côté, and M. Verma, "Water quality assessment of a constructed wetland treating landfill leachate and industrial park runoff," The American Journal of Environmental Sciences, vol. 4, no. 2, pp. 111-120, 2008.

[35] N. Stone, J. L. Shelton, B. E. Haggard, and H. K. Thomforde, "Interpretation of water analysis reports for fish culture," SRAC Publication no. 4606, Southern Regional Aquaculture Centre (SRAC), 2013.

[36] J. K. Buttner, R. W. Soderberg, and D. E. Terlizzi, "An introduction to water chemistry in fresh water aquaculture," NRAC Fact Sheet 170-1993, Northeastern Regional Aquaculture Centre (NRAC), 1993.

[37] A. Qayyum, M. Ayub, and A. B. Tabinda, "Effect of aeration on water quality, fish growth and survival in aquaculture ponds," Pakistan Journal of Zoology, vol. 37, no. 1, pp. 75-80, 2005.

[38] S. M. Banerjea, "Water quality and soil condition of fish ponds in some states of India in relation to fish production," Indian Journal of Fisheries, vol. 14, pp. 115-144, 1967.

[39] A. Bhatnagar and G. Singh, "Culture fisheries in village pondsa multi location study in Haryana, India," Agriculture and Biology Journal of North America, vol. 1, no. 5, pp. 961-968, 2010. 
[40] S. Kausik, M. S. Agarkar, and D. N. Sakesena, "Distribution of phytoplankton in riverine water in Chambal area, Madhyapradesh," Bionature, vol. 12, p. 17, 1992.

[41] A. Bhatnagar and P. Devi, "Water quality guidelines for the management of pond fish culture," International Journal of Environmental Sciences, vol. 3, no. 6, pp. 1980-2009, 2013. 

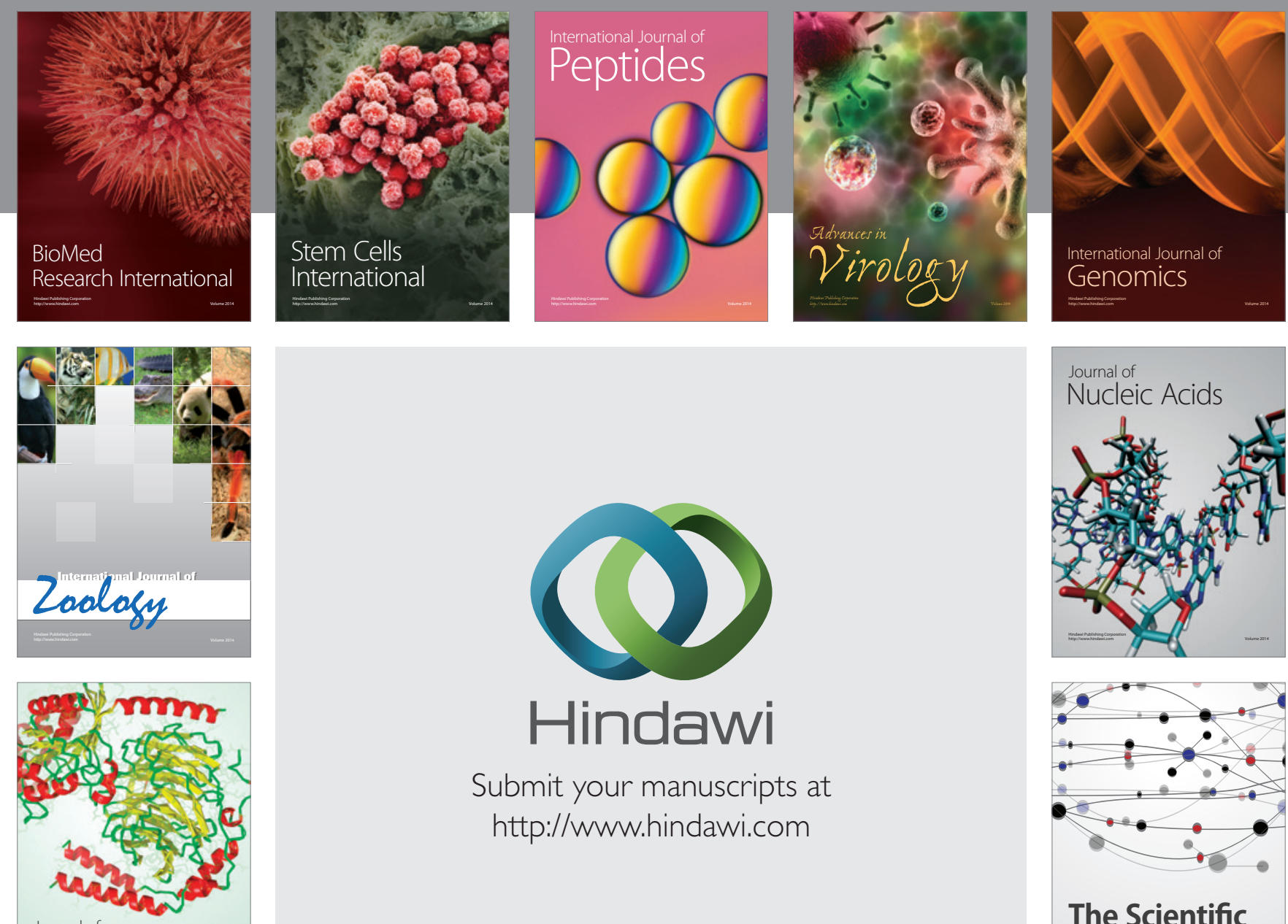

Submit your manuscripts at

http://www.hindawi.com

Journal of
Signal Transduction
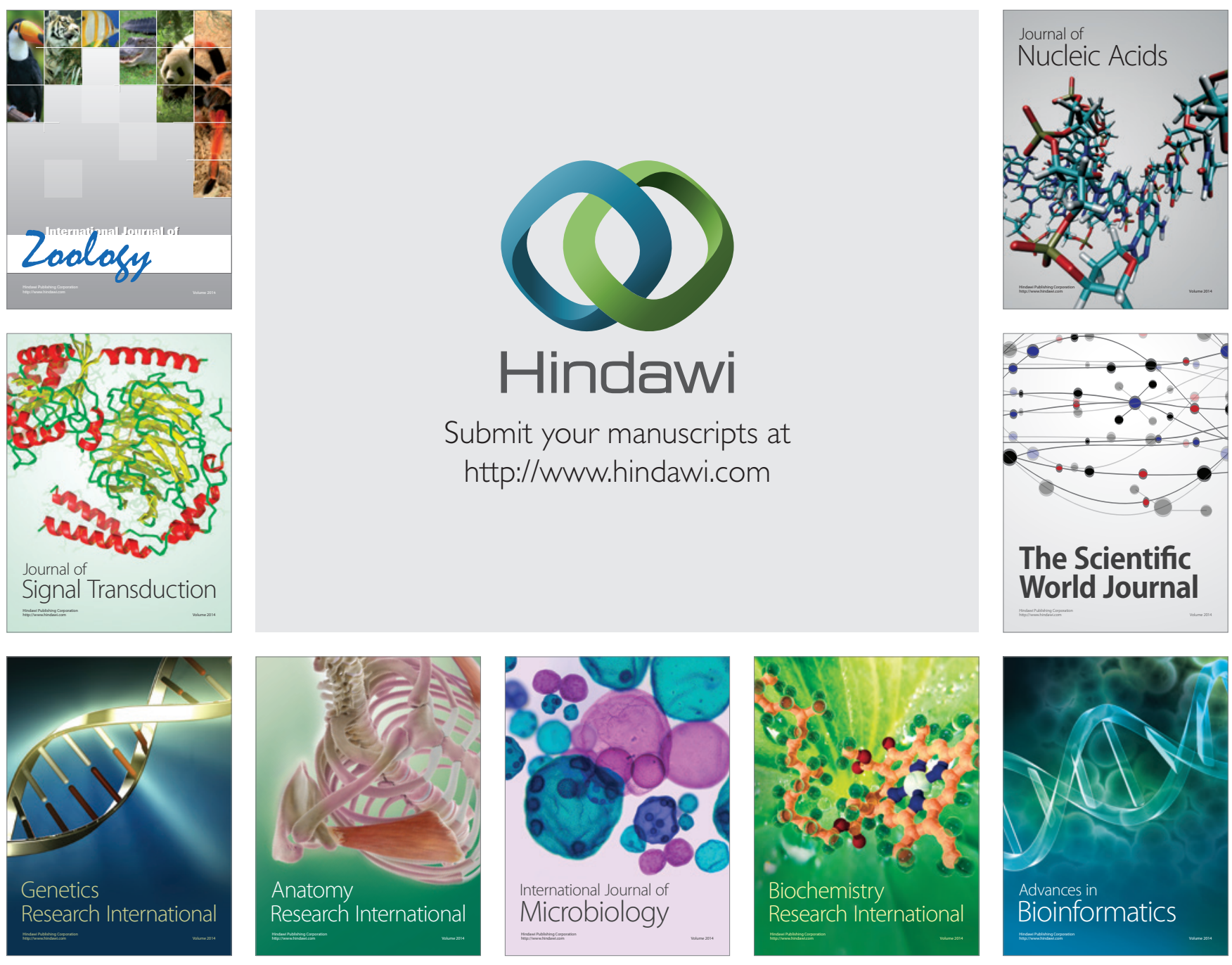

The Scientific World Journal
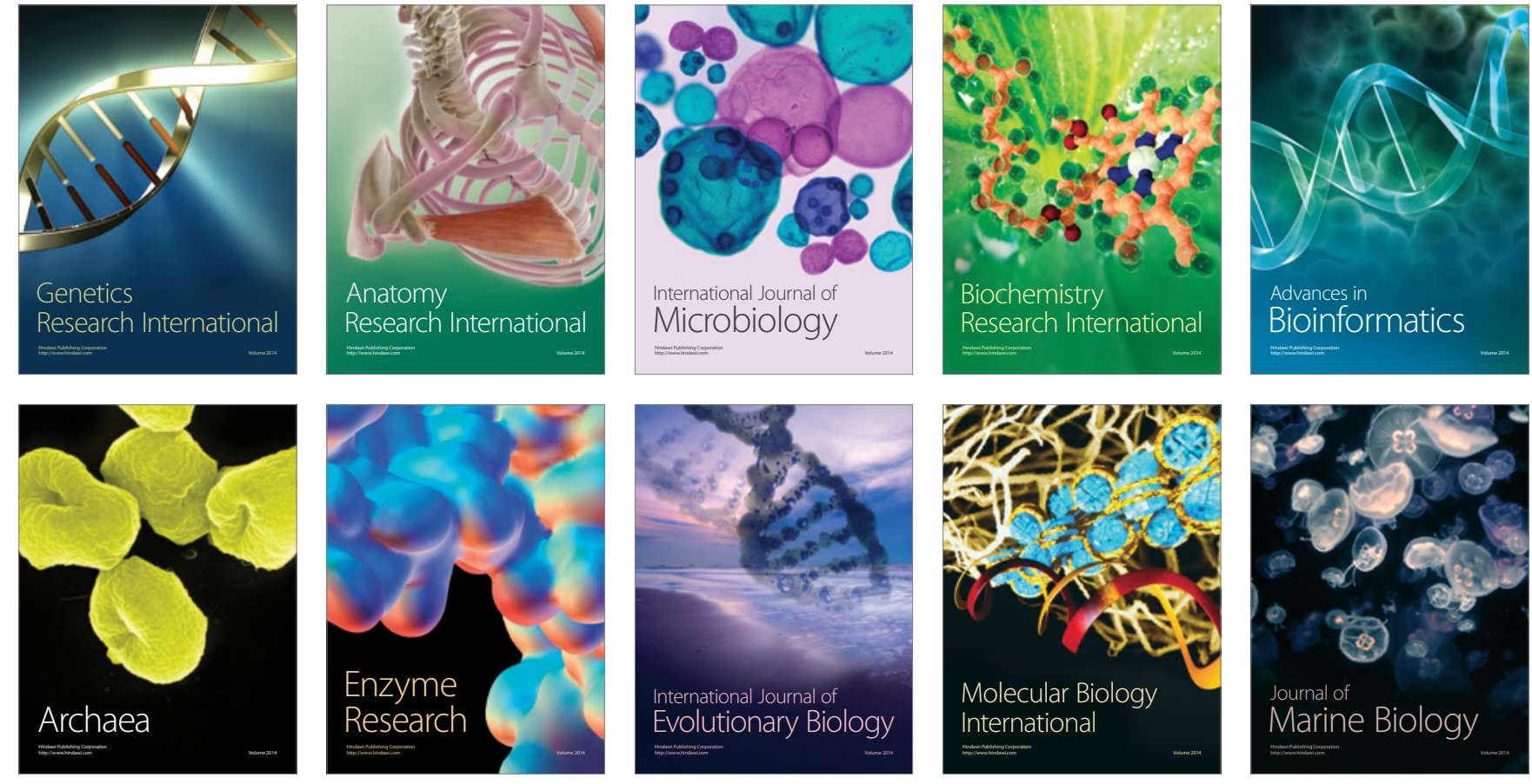